\title{
Forest Landscape Restoration under Global Environmental Change: Challenges and a Future Roadmap
}

\author{
Florent Noulèkoun $^{1}{ }^{\circledR}$, Sylvanus Mensah ${ }^{2}\left(\right.$, Emiru Birhane ${ }^{3}$, Yowhan Son ${ }^{1}$ and Asia Khamzina ${ }^{1, *(D)}$ \\ 1 Division of Environmental Science and Ecological Engineering, College of Life Science and Biotechnology, \\ Korea University, 145 Anam-Ro, Seongbuk-Gu, Seoul 02841, Korea; florentnoulekoun@yahoo.fr (F.N.); \\ yson@korea.ac.kr (Y.S.) \\ 2 Laboratoire de Biomathématiques et d'Estimations Forestières, Faculté des Sciences Agronomiques, \\ Université d'Abomey-Calavi, Cotonou 04 BP 1525, Benin; sylvanus.m89@gmail.com \\ 3 Department of Land Resources Management and Environmental Protection, College of Dryland Agriculture \\ and Natural Resources, Mekelle University, 231 Mekelle, Ethiopia; emiru.birhane@gmail.com \\ * Correspondence: asia_khamzina@korea.ac.kr
}

check for updates

Citation: Noulèkoun, F.; Mensah, S.; Birhane, E.; Son, Y.; Khamzina, A. Forest Landscape Restoration under Global Environmental Change: Challenges and a Future Roadmap. Forests 2021, 12, 276. https:// doi.org/10.3390/f12030276

Received: 21 December 2020

Accepted: 24 February 2021

Published: 28 February 2021

Publisher's Note: MDPI stays neutral with regard to jurisdictional claims in published maps and institutional affiliations.

Copyright: (C) 2021 by the authors Licensee MDPI, Basel, Switzerland. This article is an open access article distributed under the terms and conditions of the Creative Commons Attribution (CC BY) license (https:// creativecommons.org/licenses/by/ $4.0 /)$.

\begin{abstract}
The adverse impacts of ecosystem degradation have raised the need for forest landscape restoration (FLR) to be included in international sustainability agendas. However, the path towards successful FLR implementation faces numerous biophysical, socioeconomic and governance challenges because FLR operates within complex socioecological systems. In the present study, we review and discuss FLR challenges in the context of global environmental change. We propose a roadmap consisting of five interlinked steps to overcome these challenges: (1) advancing ecological knowledge supporting FLR, (2) adapting FLR management to environmental change through strengthening globally distributed experimental networks, (3) implementing modelling approaches, (4) improving socioeconomic and governance dimensions, and (5) developing evidence-based knowledge platforms. The roadmap offers an iterative and adaptive framework for the continuous evaluation and improvement of FLR strategies and outcomes.
\end{abstract}

Keywords: environmental change; evidence-based platform; functional restoration; participatory monitoring; silvicultural management

\section{Introduction}

Land degradation driven by large-scale deforestation, agricultural intensification, unsustainable land resource management, and climate change has resulted in a significant decline in global biodiversity and ecosystem functions and associated services, with consequent negative impacts on nature and humanity [1,2]. To address these issues, the international community has committed to restoring 350 million hectares of degraded ecosystems by 2030 as part of the agreements under the Bonn Challenge [3]. Underlying the Bonn Challenge is the forest landscape restoration (FLR) approach, which aims to restore ecological integrity and improve human well-being [4]. FLR balances both biophysical and socioeconomic outcomes and promotes a triple-win scenario in terms of biodiversity conservation, ecosystem service (ES) supply and livelihood improvement [3-6].

While FLR offers a promising future for environmental sustainability, the path towards achieving the ambitious targets of large-scale FLR remains unclear due to a poor understanding of the biophysical, socioeconomic and governance obstacles and the complexity of integrating multiple benefits, scales, competing interests and priorities in balancing biodiversity, ESs and livelihoods [6-11]. These challenges are further exacerbated by global environmental changes, such as rapid population growth, extreme climate events and altered land-use patterns, which in turn heightens the importance of re-thinking how degraded ecosystems are restored $[3,8,12,13]$ (Figure 1). Achieving meaningful success in FLR in a rapidly changing world requires a socioecological system (SES) framework that 
takes into account the challenges and opportunities presented by the complex interactions between ecological entities, processes and people [14]. Though there is no "one-size-fits-all" approach for the successful implementation of FLR, with an array of strategies adapted to specific contexts needing to be considered $[8,9,15,16]$, little guidance exists on how to design FLR strategies that will result in landscapes that are resilient to the continuously evolving natural, socioeconomic and political environments and that are able to sustain the provision of various goods and services [17,18]. Indeed, inadequate consideration of global environmental changes will limit the persistence of restored ecosystems (Figure 1).

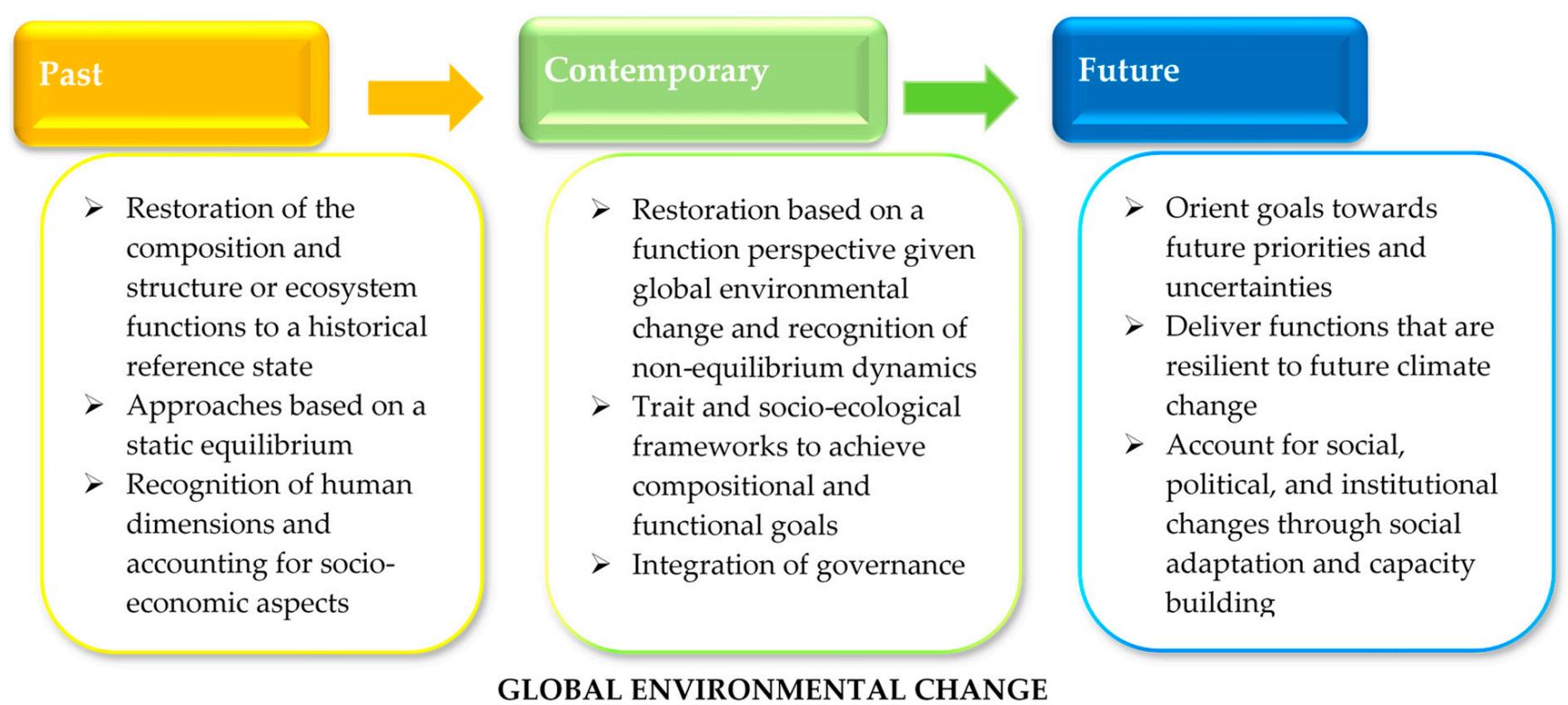

Figure 1. Framing FLR under global environmental changes. Traditionally, FLR has focused on restoring species composition and structure that would lead to desired functions (e.g., ecosystem services) with an ecological view of the equilibrium in an unchanging environment, while accounting for human dimensions to provide socioeconomic benefits for communities. Due to growing recognition of non-equilibrium dynamics and persistent global environmental changes over time, contemporary FLR uses trait and socioecological system (SES) frameworks in combination with governance to achieve dynamic and process-based restoration goals. In an era of socioenvironmental change and uncertainty, sustainable FLR should increasingly aim to deliver functions that are resilient to future climate change based on a new understanding of ecological processes and to take greater account of the human dimensions in terms of social adaptations and capacity building. Source: Modified from [19].

In this review, we summarize and discuss key challenges for FLR in the context of global environmental changes, and propose a roadmap to overcome these obstacles. We reflect on the extensive literature that has emerged in the last decade on the reasons for success and failure in FLR activities, the theories for and approaches to ecological restoration, current knowledge on the effects of global environmental changes on FLR implementation, the impacts of policies and other actions that have been adopted worldwide to ensure successful FLR, and the context-dependency of FLR initiatives. We aim to assist FLR stakeholders including practitioners, researchers, engineers, landscape architects and policymakers in the implementation of FLR by providing a framework that facilitates a systematic approach to efficient FLR.

\section{Key FLR Challenges}

\subsection{Relevance of Historical Knowledge}

A number of studies have advocated the need to consider historical ecosystem conditions as a target and reference for FLR $[3,9,20]$. This is because current forest conditions are often the result of past land use types and ecological processes that leave long-term 
legacies [21]. Historical knowledge also provides a reference for defining compositional or functional end, points and for identifying future trajectories [3]. However, concern about the impact of global environmental changes on ecosystems has led to debate on the usefulness of history as a frame of reference because the most feasible future conditions are likely to strongly depart from past trends while being incrementally different from the current state $[20,22]$. On the other hand, the dependence of the current state of an ecosystem on its history of anthropogenic disturbance, i.e., its hysteresis, may delay or prevent its recovery to its original or target state [23]. Thus, historical knowledge can serve only as a guide and not as a template in defining restoration targets and understanding long-term population dynamics under past climatic conditions $[9,20,24,25]$. While looking to the past is easier than predicting the future, historical bias and uncertainty, the difficulty in choosing an appropriate historical time period, and the paucity of information on long-term forest dynamics undermine the usefulness of historical knowledge for FLR $[14,20,26,27]$.

\subsection{Site Selection}

FLR is implemented at the landscape scale, but it remains difficult to define the boundaries of a landscape [28] because it stretches over wide areas, crossing several administrative jurisdictions including municipalities, provinces and transboundary regions $[8,10]$. Hence, although it may target the landscape, FLR interventions tend to take place locally with the expectations that a combination of local actions will influence the landscape [8]. Practically, the selection of an intervention site is constrained by the spatial and temporal heterogeneity of the landscape in terms of its physical, ecological and social characteristics. Deciding what to restore and where (as well as the opposite consideration, when not to attempt ecological restoration) remains a key challenge for FLR efforts $[16,23,29]$. Social restrictions, including the unwillingness of landowners to allocate land for restoration due to increasing population density, conflict over dwindling natural resources and the general lack of awareness, further influence the selection of sites for FLR [11,30].

\subsection{Choice of Restoration Approach}

A major determinant of the success of FLR is the choice of the restoration approach, which involves several practical considerations (Table 1). Challenges arise from the lack of clarity on key concepts related to FLR (e.g., the definition of forest, rehabilitation vs. reclamation, and reintroduction vs. rewilding), which prevents clear restoration goals from being established and appropriate strategies to achieve these goals from being selected $[8,20,31]$. The selection of the most effective FLR approach is further hindered by context dependency and trade-offs between a suite of ecological and human factors that affect forest recovery. These factors include natural ecosystem resilience, past land-use history, context (i.e., the surrounding landscape matrix) [16,18], intended outcomes (i.e., restoration to the past or future), the state of land degradation, financial constraints and the time frame [32,33]. For example, when land degradation is less severe and an appropriate context prevails (Table 1), natural regeneration may represent the most suitable and cost-effective option to improve and conserve biodiversity [8,32]. However, it may take years for natural recovery processes to produce positive changes. Thus, a shift towards more resource-intensive alternatives, such as active restoration through the planting of carefully selected native or exotic trees and assisted natural regeneration, can hasten the recovery of ecosystem functions and generate a range of positive economic and social FLR outcomes. Restoration costs naturally increase with the degree of degradation, representing a significant barrier for investment, particularly for active restoration worldwide $[16,32,33]$. 
Table 1. Practical considerations for the selection of an FLR approach.

\begin{tabular}{|c|c|c|c|}
\hline & \multicolumn{3}{|c|}{ Restoration Approaches } \\
\hline & Passive & Active & Mixed \\
\hline Examples & Natural regeneration & Afforestation/reforestation & Assisted natural regeneration \\
\hline $\begin{array}{l}\text { Level of human } \\
\text { intervention (labour) }\end{array}$ & Mild & Intensive & Moderate and intensive \\
\hline Degree of site degradation & Low & Severe & Moderate \\
\hline $\begin{array}{l}\text { Time needed } \\
\text { for positive outcomes }\end{array}$ & Very long & Short & Long \\
\hline Cost of action & Low & High & Medium \\
\hline Context & $\begin{array}{l}\text { Available seed bank and } \\
\text { dispersal agents } \\
\text { Abundance of } \\
\text { residual vegetation } \\
\text { Proximity of forest remnants }\end{array}$ & $\begin{array}{l}\text { No or very low seed banks } \\
\text { Bare land devoid of tree cover } \\
\text { No proximity of residual } \\
\text { vegetation to } \\
\text { attract dispersal agents }\end{array}$ & $\begin{array}{l}\text { Insufficiently dense seed rain } \\
\text { Lack of seed sources } \\
\text { Presence of disturbances (e.g., } \\
\text { fire and herbivory) }\end{array}$ \\
\hline Methods & "Let nature take its course" & $\begin{array}{c}\text { Direct seeding } \\
\text { Planting seedlings and/or } \\
\text { saplings of desirable native } \\
\text { and/or exotic species }\end{array}$ & $\begin{array}{l}\text { Enrichment planting by direct } \\
\text { seeding or tree planting }\end{array}$ \\
\hline $\begin{array}{l}\text { Desired silvicultural } \\
\text { management }\end{array}$ & $\begin{array}{l}\text { Site preparation (e.g., bedding, } \\
\text { mounding, scarification) }\end{array}$ & $\begin{array}{c}\text { Site preparation } \\
\text { (e.g., bedding, mounding) } \\
\text { Removal of unwanted species } \\
\text { Partial removal of the canopy } \\
\text { Field fertilization/soil } \\
\text { amendments, irrigation } \\
\text { Thinning and pruning } \\
\text { Protection from disturbances }\end{array}$ & $\begin{array}{c}\text { Site preparation } \\
\text { (e.g., bedding, mounding) } \\
\text { Erection of bird perches } \\
\text { Removal of herbaceous weeds } \\
\text { Implementation of fire and } \\
\text { grazing prevention measures } \\
\text { Partial removal of the canopy } \\
\text { Field fertilization/ } \\
\text { soil amendments }\end{array}$ \\
\hline
\end{tabular}

\subsection{Species Selection}

Planting remains the primary focus of many global, regional and national FLR initiatives, including the UN Sustainable Development Goals (SDGs) 14 and 15 [34] and Africa's Great Green Wall initiative (http:/ / www.grandemurailleverte.org/ accessed on 21 December 2020). However, the selection of candidate plant species is challenged by the lack of proper matching of species to restoration sites based on current and future site conditions, and there runs a risk of invasion by exotic species $[15,35,36]$. In particular, a knowledge gap exists when it comes to assessing the suitability of particular species for planting on degraded land, which is the basis for successful (active) restoration. For example, the lack of appropriate matching of local conditions with species suitability has led to the planting of "thirsty trees" in semi-arid regions of China under their large-scale afforestation projects, which resulted in further degradation of the environment (e.g., reduced vegetation diversity and cover, and increased water shortages) [37]. Deciding which species to plant is a decision that is based on the objectives of the project, the likelihood of tree establishment, and the availability of high-quality genetic material $[8,31]$. Because mixing functionally divergent species provides the opportunity for coexistence and complementary resource use, objectives often emphasize desirable functional traits (e.g., growth rate, wood density) and types (e.g., native vs. exotic), which in turn dictate the selection of candidate species [38-40]. However, our understanding of which traits or combination of trait values will guarantee successful establishment is still shallow [27]. While procuring sufficient seed and seedling stock of high quality is a critical first step for the success of all planting techniques [41,42], little knowledge exists on how and from where to obtain regeneration material with the desired properties for sites under restoration and how to cost-effectively cultivate plants in nurseries [9,41,42]. 


\subsection{Silvicultural Management}

Adding to the potential difficulties of species selection is the lack of silvicultural management to overcome biotic and abiotic constraints that occur at restoration sites. For example, mechanical site preparation is often required to safeguard natural and artificial regeneration, with requirements depending on the severity of the prior disturbances. In addition, herbivory poses one of the greatest challenges for forest regeneration in Europe and North America [9] while, in dry tropical areas, nutrient and water limitations on degraded land and the proliferation of natural enemies may hamper the success of FLR. Therefore, silvicultural management is critical to ensuring the success of FLR, especially in its very early stages e.g., $[35,39,40]$ (Table 1 ). For example, studies on the restoration of degraded agricultural lands in drylands of West Africa and Central Asia revealed that irrigation and fertilization facilitated forest establishment and boosted the early growth of planted trees $[40,43,44]$. In later stages of development, additional silvicultural interventions such as thinning and pruning may be needed for the sustainable management of planted forests.

Despite its importance, the use of silvicultural management in FLR has not received significant attention. Much of the field evidence that is available is based on the silvicultural management of industrial plantations that include few species with well-known silviculture systems $[9,45]$. There is also a lack of adaptive silvicultural techniques developed for mixed-species ecosystems at the site or landscape scale. The increasing focus on the restoration of degraded ecosystems thus demands new techniques of seed handling and seedling production, planting and management $[9,45]$. However, most countries have little experience in establishing such regeneration systems [9], and knowledge on the application of concepts and frameworks supporting plant community management, such as the "response-and-effect" trait framework [46], remains limited. Moreover, the lack of awareness of the importance of silvicultural practices and insufficient incentives represent major obstacles to the widespread incorporation of silviculture into FLR planning [47].

\subsection{Climate Change and Other Disturbances}

Trees, the central component of FLR, are vulnerable to natural and anthropogenic disturbances $[48,49]$, as are restored forest landscapes. Extreme weather events (e.g., severe drought) and novel climate-induced disturbances, such as pest and disease outbreaks, are likely to alter the ecological processes underlying the recovery of the forest structure and functions, resulting in changes (e.g., a shift in species distribution ranges) that are not reversible or desirable, thus jeopardizing the sustainability of restored landscapes [14,22]. However, predicting the forest growth and its species-specific response to the changing climate is hindered by the system complexity, incomplete knowledge of plant-soil-climate causal relationships, and the inability to accurately predict the future climate. While disturbances such as windthrow and forest fire are integral to forest structural dynamics, an increase in their frequency and/or range as a result of direct human activity or anthropogenic environmental changes may limit the structural elements of the forest and sources of microsite diversity, adding to the difficulty of restoration [50]. Ultimately, changes in drought and wildfire severity, frost hardiness zones, flood events, pest and disease outbreaks, land use and land cover and competitors' populations will affect species range distributions and adaptiveness in the future. However, our understanding of these critical issues, which may have long-lasting consequences for the success of FLR, is still in its infancy and the use of advanced methods such as modelling for navigating dynamic ecological functions and processes is constrained by errors and uncertainties in model predictions $[9,51]$.

\subsection{Governance and Socio-Economic Challenges}

Evidence suggests that the success of FLR depends on the support, contribution and cooperation of all stakeholders at all levels, as well as the system of governance in place $[9,10,52]$. However, the lack of true stakeholder engagement remains a major challenge for the successful implementation of FLR [10]. Moreover, FLR tends to occur within 
environments characterized by weak systems of governance, histories of land tenure and rights conflict, a lack of policy coordination and structural discrimination against women and indigenous communities [8-10,34,52]. It is thus essential to ensure that FLR initiatives do not perpetuate historical injustices or the marginalization of underrepresented social groups but rather promote the equitable participation of all stakeholders [52]. However, the process of establishing strong and coherent policies that reconcile the conflicting interests of various actors, including state governance units, and that suit the multi-functionality of the target landscapes is hindered by the transboundary nature of landscapes (The transboundary nature of landscapes means that FLR is shaped and influenced by diverse elements of governance (i.e., decision-making, policies and institutions) including from other sectors (e.g. tourism and industry), and at scales ranging from local to international.) [8]. These conflicting issues are aggravated at local level, where local and indigenous governance, aspects such as customary tenure and land-use decision-making, may not align with national-level forest resource use and legislation [10]. The successful implementation of FLR can be further undermined by the constantly changing legal and social settings surrounding the restoration of a landscape, driven by population growth, globalization, land-use changes and shifts in policy, which means that FLR needs to adapt to these changes $[8,17]$. Other related challenges such as inadequate planning and setting of priorities [53], the lack of conceptual clarity and clear guidelines for evaluating the effectiveness of FLR interventions, insufficient and short-term funding, the risk of an "enthusiasm gap" arising due to unmet expectations [8,9] and the "knowing-doing" gap [31] also may capsize FLR efforts in the long term.

\section{Roadmap for Sustainable FLR}

To address the challenges identified above, we propose a roadmap consisting of five steps towards sustainable FLR, as summarized in Figure 1. Key elements of each step of the roadmap are summarized in Figure 2.

\subsection{Step 1: Advancing Ecological Knowledge to Support FLR}

In order to achieve successful FLR in the face of rapid environmental change, it is crucial to solidify knowledge on the ecological processes underlying the re-introduction or re-assemblage of plant communities. Changing biotic and abiotic conditions have forced ecosystems beyond certain thresholds to produce novel states that may have no historical analog $[54,55]$, suggesting that the restoration targets and criteria for success should be re-adjusted towards future priorities [20] with emphasis on resilience to projected environmental changes and less reliance on historical reference frame [14,27]. Because restoration may result in "novel ecosystems" with novel compositional structure and spatial distribution under changing environments $[11,19,20]$, we suggest a shift of focus in FLR from compositional goals to functional targets, as also proposed by numerous other studies $[14,27,31,46,56]$.

Functional restoration aims to maintain ecosystem function and to design multifunctional landscapes with a focus on the sustainability of multiscale ecosystem processes [31,56]. Over the past decades, conceptual and technological advances in traitenvironment relationships and community assembly have laid a solid ecological foundation for functional restoration [14]. A promising functional approach for FLR is the "response-and-effect trait" framework, which unifies the processes of community responses to environmental conditions and the effects of organisms on ecosystem functions [27].

The framework can allow practitioners to select the most appropriate species to guarantee restoration success and assess the long-term dynamics of restored communities using the "environmental filtering" theory [27]. More importantly, trait-based predictive models can be applied under experimental conditions to test hypotheses about which traits and species combinations will be most effective in achieving restoration goals and in ensuring optimum fitness under future climate change scenarios [27] (Steps 2, 3). 


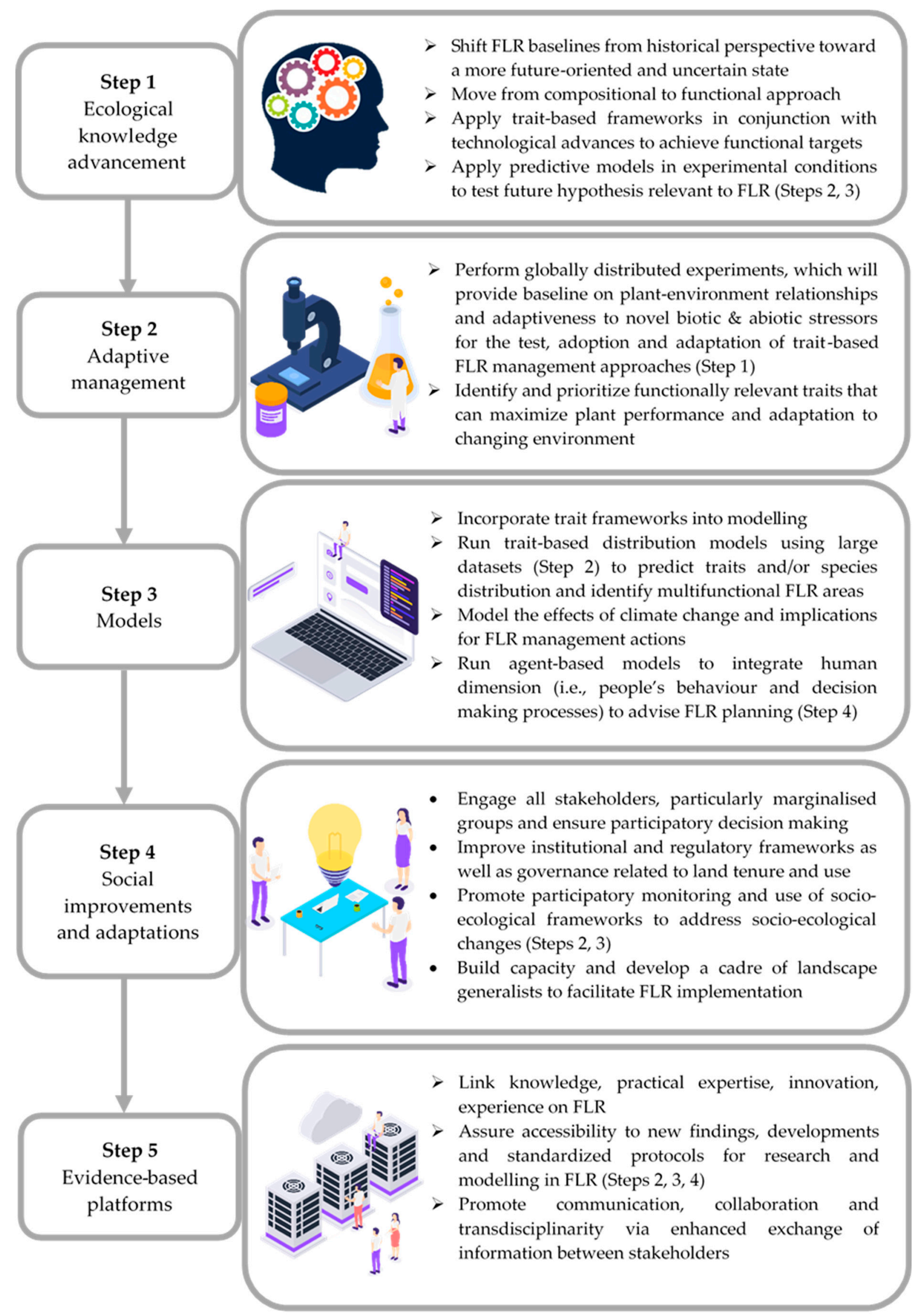

Figure 2. Proposed roadmap including concrete suggestions for the successful implementation of FLR under global environmental change. Interconnectedness within the roadmap is indicated by the working steps in parentheses. 
Furthermore, the success of trait-based FLR can be enhanced by other concept-based practices such as assisted migration, which can be applied to overcome species dispersal limitations under climate change [20]. Technological advances in treatments to enhance seed germination, high-throughput DNA sequencing analysis, GIS and remote sensing tools can also augment the success rate of FLR efforts [14] by enabling, for example, the development of a decision-support tool for identifying suitable tree species (e.g., vegetationmap4africa; https: / /vegetationmap4africa.org/Home.html, accessed on 21 December 2020) and multifunctional areas for FLR [57]. Dumroese et al. (2015) convincingly illustrated how functional restoration, assisted migration and biotechnology can be combined for successful FLR. Integrating traditional ecological knowledge (TEK) with trait-based models can further enhance community support and the effectiveness of FLR initiatives because TEK is mostly practice-based and has been tested across generations [58]. In sum, we suggest the use of concept- or trait-based approaches in conjunction with technological advancements and TEK to achieve functional FLR goals. These approaches should be continuously tested for different experimental conditions to accumulate the ecological and technological knowledge necessary for adjusting FLR interventions to a changing environment (Steps 2 and 3).

\subsection{Step 2: Adaptive FLR Management}

Field- and large-scale experiments and observational studies focusing on plantenvironment relationships along gradients of environmental factors and management actions are necessary to test the effectiveness of concept-driven FLR e.g., [12,17]. Complex interactions resulting in community responses (i.e., functions) and plant trait adaptations require that multiple aspects of the environment (e.g., light intensity, nutrient availability and temperature and rainfall variability) are considered simultaneously. In this regard, achieving successful FLR under environmental change will require adaptive management through which initial conservation and management plans are modified as their limited degree of success becomes apparent. Therefore, integrating and manipulating the effects of the variability of environmental factors on community components through holistic experiments and observational studies would be needed to provide insights into the response of traits and ecophysiological processes to the drivers of global change, which can serve as a basis for species selection, modeling [27,40] (Steps 1 and 3) and optimization of FLR management according to significant evaluation outcomes. This is particularly crucial for producing, for example, stress-resistant planting stocks [41,42] and tailoring silvicultural practices to changing plant requirements. This information is also needed to test context dependency and the appropriateness of concepts and technologies in different restoration scenarios. We suggest that experiments be conducted globally [59] to test for the effects of current and projected environmental variability on functional traits and groups to generate new hypotheses for trait-function-environment relationships necessary for adaptive management, thus improving FLR approaches (Step 1).

\subsection{Step 3: Modelling}

Ensuring the survival of plant communities and maintaining the functions of restored forests remains one of the biggest challenges of FLR given the uncertainty in projecting future changes. Nonetheless, attempts have been made to predict future climate, offering opportunities to explore the performance of plant communities under possible climate change scenarios using models [60]. A pre-requisite for landscape-scale modeling is data with sufficient geographic coverage, which can be obtained from experimental and observational studies (Step 2). This data would enable the application of up-to-date modelling approaches to support FLR. Evidence suggests that modeling using trait frameworks provides a means to advance ecological understanding in terms of plant-soil-climate interactions [61,62], which is vital to effective FLR (Step 1). For example, using a joint species distribution modelling (SDM) approach that integrates trait-environment relationships has been shown to improve the predictive ability of models in identifying suitable niches 
where species can thrive under future climates and in determining where FLR activities are worth implementing [59]. Process-based models can also be used to guide FLR activity, as they include both traits and functions and allow predictions of ecosystem functioning in response to climate change and management scenarios [47,48,59]. Another relevant approach is agent-based modeling, which has the ability to integrate spatial and socioeconomic dimensions through the representation of landscape characteristics and human decision-making processes [14]. Agent-based models could be used for the analysis of relevant policy incentive scenarios in coupled human-nature systems (Step 4) with support from trait-based approaches to expand their utility for FLR. The development of modelling scenarios should follow a participatory approach (Step 4).

\subsection{Step 4: Social Improvements and Adaptations}

The complexity of landscapes as socioecological systems calls for greater focus on the sociopolitical dimensions of FLR. A conducive socioeconomic and political environment has generally been recognized as key to effective science-based FLR [8,10,63-65]. Consequently, establishing institutional and regulatory frameworks that include integrative policies and consistently enforcing them would enhance the likelihood of FLR success [65]. Other important and nonmutually exclusive considerations for successful FLR implementation include participation, cost-effectiveness, tenure and usage rights, conflicts of interest and social and financial capital. More specifically, promoting participatory decision-making by engaging all relevant stakeholders including marginalized groups (e.g., women) at all levels would create ownership and trust which, in turn, would increase the effectiveness of decision-making and generate broader buy-in and social learning [9,10,52]. Establishing systems that provide sustained incentives for community members and allow for the equitable sharing of the costs and benefits would also be essential to ensure long-term FLR outcomes $[31,66]$. Enhancing governance related to land tenure and rights (e.g., land titling), embracing conflict resolution processes and strengthening local capacity in the socioeconomic, ecological and technological elements of FLR would further promote successful FLR $[8,65,66]$.

Because the world around restored landscapes will be changing, participatory monitoring and social adaptations to global change will be key to maintaining momentum over the time needed to achieve positive FLR outcomes and to overcome the enthusiasm gap. In particular, participatory monitoring would enable the evaluation of FLR success based on collaboratively selected indicators and provide effective feedback for adaptive management $[8,63]$. Promising tools for participatory monitoring that combine social and ecological perspectives and that track processes of landscape change include participatory mapping and simulation modeling $[31,67]$ (Step 3). Understanding the role of social changes in the FLR process would require the use of socioecological frameworks, coupled with inter- and trans-disciplinary SES research (Step 2). More importantly, we support the recommendation by Stanturf et al. (2019) of employing "landscape generalists" who would facilitate FLR implementation, bringing together technical knowledge with sensitivity to socioenvironmental changes.

\subsection{Step 5: Evidence-Based Platforms}

Incorporating novel research and modelling findings, practical expertise, innovations, TEK and experience with FLR into local and global evidence platforms or networks would be a useful avenue to pursue for future FLR interventions. These platforms are necessary to understand context dependency and provide information on challenging questions related to where, when and why FLR interventions are successful [14]. The information would improve the ability of restoration practitioners to design FLR that is resilient to future environmental changes. Standardized protocols for field and modeling approaches and generic indicators of FLR success could be made available for download (Steps 2, 3 and 4). The platform would also promote the exchange of information between FLR stakeholders (e.g., scientists, land managers, communities, government agencies and the private sector), 
which in turn, would enhance communication, collaboration and transdisciplinarity at the local, regional and global levels and could bridge the "knowing-doing" gap. The new generation plantation (NGP) platform [68] is a promising example of this, which can serve as the basis for developing more integrative and transdisciplinary evidence-based platforms to support FLR.

\section{Conclusions}

FLR is a promising approach for meeting global restoration commitments. However, as a dynamic process occurring in complex SESs exposed to global environmental changes, FLR faces several challenges in design, prioritization of intended outcomes, management, stakeholder engagement as well as other socioeconomic, and governance constraints. In this paper, we suggest a roadmap to tackle these challenges. The roadmap includes the building of sound ecological knowledge (Step 1), which can be continuously evaluated and updated through coordinated experiments (Step 2) and modeling approaches (Step 3), and the improvement of socioeconomic and governance factors with an emphasis on participation, monitoring, and social adaptation (Step 4). Information from these four steps can be collected in evidence-based platforms (Step 5) to guide adaptive FLR. The roadmap thus promotes an iterative and adaptive process, aiming to continuously improve and adjust FLR interventions for changing environments.

Author Contributions: Conceptualization, F.N.; methodology, F.N. and A.K.; writing—original draft preparation, F.N.; writing-review and editing, F.N., S.M., E.B., Y.S., A.K. All authors have read and agreed to the published version of the manuscript.

Funding: This research received no external funding.

Acknowledgments: This study was carried out with the support of 'R\&D Program for Forest Science Technology (Project No. 2020181A00-2122-BB01) ' provided by Korea Forest Service (Korea Forestry Promotion Institute). The support of the BK21 (Brain Korea 21 Program for Leading Universities and Students) FOUR program (Grant No. 4120200313708) funded by the National Research Foundation of Korea (NRF), the support of the NRF Grant No. 2019R1I1A1A01064336 and the support of O-Jeong Resilience Institute (OJERI) are all gratefully acknowledged.

Conflicts of Interest: The authors declare no conflict of interest.

\section{References}

1. Reid, W.V.; Mooney, H.A.; Cropper, A.; Capistrano, D.; Carpenter, S.R.; Chopra, K.; Dasgupta, P.; Dietz, T.; Duraiappah, A.K.; Hassan, R.; et al. Ecosystems and Human Well-Being - Synthesis: A Report of the Millennium Ecosystem Assessment; Island Press: Washington, DC, USA, 2005; ISBN 978-1-59726-040-4.

2. Nkonya, E.; Mirzabaev, A.; von Braun, J. Economics of Land Degradation and Improvement: An Introduction and Overview. In Economics of Land Degradation and Improvement-A Global Assessment for Sustainable Development; Nkonya, E., Mirzabaev, A., von Braun, J., Eds.; Springer International Publishing: Cham, Switherlands, 2016; pp. 1-14. ISBN 978-3-319-19168-3.

3. Suding, K.; Higgs, E.; Palmer, M.; Callicott, J.B.; Anderson, C.B.; Baker, M.; Gutrich, J.J.; Hondula, K.L.; LaFevor, M.C.; Larson, B.M.H.; et al. Committing to Ecological Restoration. Science 2015, 348, 638-640. [CrossRef] [PubMed]

4. Reed, J.; van Vianen, J.; Barlow, J.; Sunderland, T. Have Integrated Landscape Approaches Reconciled Societal and Environmental Issues in the Tropics? Land Use Policy 2017, 63, 481-492. [CrossRef]

5. Brancalion, P.H.S.; Chazdon, R.L. Beyond Hectares: Four Principles to Guide Reforestation in the Context of Tropical Forest and Landscape Restoration: Forest and Landscape Restoration Principles. Restor. Ecol. 2017, 25, 491-496. [CrossRef]

6. Erbaugh, J.T.; Oldekop, J.A. Forest Landscape Restoration for Livelihoods and Well-Being. Curr. Opin. Environ. Sustain. 2018, 32, 76-83. [CrossRef]

7. Maron, M.; Hobbs, R.J.; Moilanen, A.; Matthews, J.W.; Christie, K.; Gardner, T.A.; Keith, D.A.; Lindenmayer, D.B.; McAlpine, C.A. Faustian Bargains? Restoration Realities in the Context of Biodiversity Offset Policies. Biol. Conserv. 2012, 155, 141-148. [CrossRef]

8. Stanturf, J.A.; Kleine, M.; Mansourian, S.; Parrotta, J.; Madsen, P.; Kant, P.; Burns, J.; Bolte, A. Implementing Forest Landscape Restoration under the Bonn Challenge: A Systematic Approach. Ann. For. Sci. 2019, 76, 50. [CrossRef]

9. Löf, M.; Madsen, P.; Metslaid, M.; Witzell, J.; Jacobs, D.F. Restoring Forests: Regeneration and Ecosystem Function for the Future. New For. 2019, 50, 139-151. [CrossRef] 
10. Mansourian, S. Governance and Forest Landscape Restoration: A Framework to Support Decision-Making. J. Nat. Conserv. 2017, 37, 21-30. [CrossRef]

11. Halme, P.; Allen, K.A.; Auninš̌, A.; Bradshaw, R.H.W.; Brūmelis, G.; Čada, V.; Clear, J.L.; Eriksson, A.-M.; Hannon, G.; Hyvärinen, E.; et al. Challenges of Ecological Restoration: Lessons from Forests in Northern Europe. Biol. Conserv. 2013, 167, 248-256. [CrossRef]

12. Aitken, S.N.; Yeaman, S.; Holliday, J.A.; Wang, T.; Curtis-McLane, S. Adaptation, Migration or Extirpation: Climate Change Outcomes for Tree Populations. Evol. Appl. 2008, 1, 95-111. [CrossRef]

13. Liang, S.; Hurteau, M.D.; Westerling, A.L. Large-Scale Restoration Increases Carbon Stability under Projected Climate and Wildfire Regimes. Front. Ecol. Environ. 2018, 16, 207-212. [CrossRef]

14. Perring, M.P.; Standish, R.J.; Price, J.N.; Craig, M.D.; Erickson, T.E.; Ruthrof, K.X.; Whiteley, A.S.; Valentine, L.E.; Hobbs, R.J. Advances in Restoration Ecology: Rising to the Challenges of the Coming Decades. Ecosphere 2015, 6, 1-25. [CrossRef]

15. Cernansky, R. How to Rebuild a Forest. Nature 2018, 560, 542-544. [CrossRef]

16. Holl, K.D.; Aide, T.M. When and Where to Actively Restore Ecosystems? For. Ecol. Manag. 2011, 261, 1558-1563. [CrossRef]

17. Stanturf, J.A. Future Landscapes: Opportunities and Challenges. New For. 2015, 46, 615-644. [CrossRef]

18. Reid, J.L.; Wilson, S.J.; Bloomfield, G.S.; Cattau, M.E.; Fagan, M.E.; Holl, K.D.; Zahawi, R.A. How Long Do Restored Ecosystems Persist? Ann. Mo. Bot. Gard. 2017, 102, 258-265. [CrossRef]

19. Perring, M.P.; Standish, R.J.; Hobbs, R.J. Incorporating Novelty and Novel Ecosystems into Restoration Planning and Practice in the 21st Century. Ecol. Process 2013, 2, 18. [CrossRef]

20. Corlett, R.T. Restoration, Reintroduction, and Rewilding in a Changing World. Trends Ecol. Evol. 2016, 31, 453-462. [CrossRef] [PubMed]

21. Jõgiste, K.; Korjus, H.; Stanturf, J.A.; Frelich, L.E.; Baders, E.; Donis, J.; Jansons, A.; Kangur, A.; Köster, K.; Laarmann, D.; et al. Hemiboreal Forest: Natural Disturbances and the Importance of Ecosystem Legacies to Management. Ecosphere 2017, 8, e01706. [CrossRef]

22. Harris, J.A.; Hobbs, R.J.; Higgs, E.; Aronson, J. Ecological Restoration and Global Climate Change. Restor. Ecol. 2006, 14, 170-176. [CrossRef]

23. Sternberg, L.D.S.L. Savanna-Forest Hysteresis in the Tropics. Glob. Ecol. Biogeogr. 2001, 10, 369-378. [CrossRef]

24. Higgs, E.; Falk, D.A.; Guerrini, A.; Hall, M.; Harris, J.; Hobbs, R.J.; Jackson, S.T.; Rhemtulla, J.M.; Throop, W. The Changing Role of History in Restoration Ecology. Front. Ecol. Environ. 2014, 12, 499-506. [CrossRef]

25. Balaguer, L.; Escudero, A.; Martín-Duque, J.F.; Mola, I.; Aronson, J. The Historical Reference in Restoration Ecology: Re-Defining a Cornerstone Concept. Biol. Conserv. 2014, 176, 12-20. [CrossRef]

26. Thorpe, A.S.; Stanley, A.G. Determining Appropriate Goals for Restoration of Imperilled Communities and Species. J. Appl. Ecol. 2011, 48, 275-279. [CrossRef]

27. Laughlin, D.C. Applying Trait-Based Models to Achieve Functional Targets for Theory-Driven Ecological Restoration. Ecol. Lett. 2014, 17, 771-784. [CrossRef]

28. Görg, C. Landscape Governance: The "Politics of Scale" and the "Natural" Conditions of Places. Geoforum 2007, 38, 954-966. [CrossRef]

29. Torrubia, S.; McRae, B.H.; Lawler, J.J.; Hall, S.A.; Halabisky, M.; Langdon, J.; Case, M. Getting the Most Connectivity per Conservation Dollar. Front. Ecol. Environ. 2014, 12, 491-497. [CrossRef]

30. Knight, A.T.; Sarkar, S.; Smith, R.J.; Strange, N.; Wilson, K.A. Engage the Hodgepodge: Management Factors Are Essential When Prioritizing Areas for Restoration and Conservation Action. Divers. Distrib. 2011, 17, 1234-1238. [CrossRef]

31. Stanturf, J.A.; Palik, B.J.; Dumroese, R.K. Contemporary Forest Restoration: A Review Emphasizing Function. For. Ecol. Manag. 2014, 331, 292-323. [CrossRef]

32. Chazdon, R.L. Beyond Deforestation: Restoring Forests and Ecosystem Services on Degraded Lands. Science 2008, 320, 1458-1460. [CrossRef] [PubMed]

33. Stanturf, J.A.; Schoenholtz, S.H.; Schweitzer, C.J.; Shepard, J.P. Achieving Restoration Success: Myths in Bottomland Hardwood Forests. Restor. Ecol. 2001, 9, 189-200. [CrossRef]

34. DeFries, R.S.; Rudel, T.; Uriarte, M.; Hansen, M. Deforestation Driven by Urban Population Growth and Agricultural Trade in the Twenty-First Century. Nat. Geosci. 2010, 3, 178-181. [CrossRef]

35. Thomas, E.; Jalonen, R.; Loo, J.; Boshier, D.; Gallo, L.; Cavers, S.; Bordács, S.; Smith, P.; Bozzano, M. Genetic Considerations in Ecosystem Restoration Using Native Tree Species. For. Ecol. Manag. 2014, 333, 66-75. [CrossRef]

36. Funk, J.L.; Cleland, E.E.; Suding, K.N.; Zavaleta, E.S. Restoration through Reassembly: Plant Traits and Invasion Resistance. Trends Ecol. Evol. 2008, 23, 695-703. [CrossRef]

37. Cao, S.; Wang, G.; Chen, L. Assessing Effects of Afforestation Projects in China: Cao and Colleagues Reply. Nature 2010, 466, 315. [CrossRef]

38. Sacande, M.; Berrahmouni, N. Community Participation and Ecological Criteria for Selecting Species and Restoring Natural Capital with Native Species in the Sahel: Restoring Natural Capital in the Sahel. Restor. Ecol. 2016, 24, 479-488. [CrossRef]

39. Khamzina, A.; Lamers, J.P.A.; Worbes, M.; Botman, E.; Vlek, P.L.G. Assessing the Potential of Trees for Afforestation of Degraded Landscapes in the Aral Sea Basin of Uzbekistan. Agrofor. Syst. 2006, 66, 129-141. [CrossRef] 
40. Noulèkoun, F.; Lamers, J.P.A.; Naab, J.; Khamzina, A. Shoot and Root Responses of Woody Species to Silvicultural Management for Afforestation of Degraded Croplands in the Sudano-Sahelian Zone of Benin. For. Ecol. Manag. 2017, 385, 254-263. [CrossRef]

41. Dumroese, K.; Landis, T.; Pinto, J.; Haase, D.; Wilkinson, K.; Davis, A. Meeting Forest Restoration Challenges: Using the Target Plant Concept. Reforesta 2016, 1, 37-52. [CrossRef]

42. Haase, D.; Davis, A. Developing and Supporting Quality Nursery Facilities and Staff Are Necessary to Meet Global Forest and Landscape Restoration Needs. Reforesta 2017, 69-93. [CrossRef]

43. Noulèkoun, F.; Khamzina, A.; Naab, J.B.; Lamers, J.P.A. Biomass Allocation in Five Semi-Arid Afforestation Species Is Driven Mainly by Ontogeny Rather than Resource Availability. Ann. For. Sci. 2017, 74, 78. [CrossRef]

44. Khamzina, A.; Lamers, J.P.A.; Vlek, P.L.G. Tree Establishment under Deficit Irrigation on Degraded Agricultural Land in the Lower Amu Darya River Region, Aral Sea Basin. For. Ecol. Manag. 2008, 255, 168-178. [CrossRef]

45. Oliet, J.A.; Jacobs, D.F. Restoring Forests: Advances in Techniques and Theory. New For. 2012, 43, 535-541. [CrossRef]

46. Suding, K.N.; Lavorel, S.; Chapin, F.S.; Cornelissen, J.H.C.; Díaz, S.; Garnier, E.; Goldberg, D.; Hooper, D.U.; Jackson, S.T.; Navas, M.-L. Scaling Environmental Change through the Community-Level: A Trait-Based Response-and-Effect Framework for Plants. Glob. Change Biol. 2008, 14, 1125-1140. [CrossRef]

47. Djalilov, B.M.; Khamzina, A.; Hornidge, A.-K.; Lamers, J.P.A. Exploring Constraints and Incentives for the Adoption of Agroforestry Practices on Degraded Cropland in Uzbekistan. J. Environ. Plan. Manag. 2016, 59, 142-162. [CrossRef]

48. Noulèkoun, F.; Khamzina, A.; Naab, J.B.; Khasanah, N.; Van Noordwijk, M.; Lamers, J.P.A. Climate Change Sensitivity of Multi-Species Afforestation in Semi-Arid Benin. Sustainability 2018, 10, 1931. [CrossRef]

49. Löf, M. Program and Book of Abstracts of the IUFRO 3rd Restoring Forest: Regeneration and Ecosystem Function for the Future; Lund, Sweden 12-14 September 2017. Report 51; Swedish University of Agricultural Sciences, Southern Swedish Forest Research Centre, Alnarp: Alnarp, Sweden, 2017; p. 109.

50. Cortina, J.; Amat, B.; Castillo, V.; Fuentes, D.; Maestre, F.T.; Padilla, F.M.; Rojo, L. The Restoration of Vegetation Cover in the Semi-Arid Iberian Southeast. J. Arid Environ. 2011, 75, 1377-1384. [CrossRef]

51. Luedeling, E.; Smethurst, P.J.; Baudron, F.; Bayala, J.; Huth, N.I.; van Noordwijk, M.; Ong, C.K.; Mulia, R.; Lusiana, B.; Muthuri, C.; et al. Field-Scale Modeling of Tree-Crop Interactions: Challenges and Development Needs. Agric. Syst. 2016, 142, 51-69. [CrossRef]

52. Basnett, B.S.; Elias, M.; Ihalainen, M.; Valencia, A.M.P. Gender Matters in Forest Landscape Restoration; CIFOR: Bogor, Indonesia, 2017.

53. Evans, K.; Guariguata, M.R.; Brancalion, P.H.S. Participatory Monitoring to Connect Local and Global Priorities for Forest Restoration. Conserv. Biol. 2018, 32, 525-534. [CrossRef]

54. Suding, K.N.; Gross, K.L.; Houseman, G.R. Alternative States and Positive Feedbacks in Restoration Ecology. Trends Ecol. Evol. 2004, 19, 46-53. [CrossRef]

55. Hobbs, R.J.; Higgs, E.S.; Hall, C. Novel Ecosystems: Intervening in the New Ecological World Order; John Wiley \& Sons: New Jersey, USA, 2013; ISBN 978-1-118-35420-9.

56. Dumroese, R.K.; Williams, M.I.; Stanturf, J.A.; Clair, J.B.S. Considerations for Restoring Temperate Forests of Tomorrow: Forest Restoration, Assisted Migration, and Bioengineering. New For. 2015, 46, 947-964. [CrossRef]

57. Schulz, J.J.; Schröder, B. Identifying Suitable Multifunctional Restoration Areas for Forest Landscape Restoration in Central Chile. Ecosphere 2017, 8, e01644. [CrossRef]

58. Mockta, T.K.; Fulé, P.Z.; Sánchez Meador, A.; Padilla, T.; Kim, Y.-S. Sustainability of Culturally Important Teepee Poles on Mescalero Apache Tribal Lands: Characteristics and Climate Change Effects. For. Ecol. Manag. 2018, 430, 250-258. [CrossRef]

59. Borer, E.T.; Harpole, W.S.; Adler, P.B.; Lind, E.M.; Orrock, J.L.; Seabloom, E.W.; Smith, M.D. Finding Generality in Ecology: A Model for Globally Distributed Experiments. Methods Ecol. Evol. 2014, 5, 65-73. [CrossRef]

60. Van Vuuren, D.P.; Edmonds, J.; Kainuma, M.; Riahi, K.; Thomson, A.; Hibbard, K.; Hurtt, G.C.; Kram, T.; Krey, V.; Lamarque, J.-F.; et al. The Representative Concentration Pathways: An Overview. Clim. Change 2011, 109, 5. [CrossRef]

61. Ke, P.-J.; Miki, T.; Ding, T.-S. The Soil Microbial Community Predicts the Importance of Plant Traits in Plant-Soil Feedback. New Phytol. 2015, 206, 329-341. [CrossRef]

62. Degen, R.; Aune, M.; Bluhm, B.A.; Cassidy, C.; Kedra, M.; Kraan, C.; Vandepitte, L.; Włodarska-Kowalczuk, M.; Zhulay, I.; Albano, P.G.; et al. Trait-Based Approaches in Rapidly Changing Ecosystems: A Roadmap to the Future Polar Oceans. Ecol. Indic. 2018, 91, 722-736. [CrossRef]

63. Stanturf, J.; Mansourian, S.; Kleine, M. (Eds.) Implementing Forest Landscape Restoration, a Practitioner's Guide; International Union of Forest Research Organizations, Special Programme for Development of Capacities (IUFRO-SPDC): Vienna, Austria, 2017; ISBN 978-3-902762-78-8.

64. Besseau, P.; Graham, S.; Christopherson, T. (Eds.) Restoring Forests and Landscapes: The Key to a Sustainable Future; International Union of Forest Research Organizations (IUFRO) on behalf of the Global Partnership on Forest and Landscape Restoration (GPFLR): Vienna, Austria, 2018; ISBN 978-3-902762-97-9.

65. Reinecke, S.; Blum, M. Discourses across Scales on Forest Landscape Restoration. Sustainability 2018, 10, 613. [CrossRef]

66. Mansourian, S. Understanding the Relationship between Governance and Forest Landscape Restoration. Conserv. Soc. 2016, 14, 267. [CrossRef] 
67. Boedhihartono, A.K.; Sayer, J. Forest Landscape Restoration: Restoring What and for Whom? In Forest Landscape Restoration: Integrating Natural and Social Sciences; Stanturf, J., Lamb, D., Madsen, P., Eds.; World Forests; Springer: Dordrecht, The Netherlands, 2012; pp. 309-323. ISBN 978-94-007-5326-6.

68. Silva, L.N.; Freer-Smith, P.; Madsen, P. Production, Restoration, Mitigation: A New Generation of Plantations. New For. 2019, 50, 153-168. [CrossRef] 